\title{
Bio-stimulation of microbial degradation of crude oil polluted soil using cow dung and plantain peels
}

\author{
Agbor R. B. ${ }^{1 \star}$ and Antai S. P. ${ }^{2}$ \\ ${ }^{1}$ Department of Genetics and Biotechnology, University of Calabar, Calabar, Cross River State, Nigeria. \\ ${ }^{2}$ Department of Microbiology, University of Calabar, Calabar, Cross River State, Nigeria.
}

Accepted 27 February, 2018

\begin{abstract}
Biostimulation of microbial degradation of crude oil-polluted soil using cow-dung and plantain peels was investigated. Top soil (0 to $20 \mathrm{~cm}$ depth) was randomly collected from four points using a Dutch auger, then bulked to form composite soil sample. Eight kilogram $(8 \mathrm{~kg})$ of each composite soil was weighed and transferred into forty five (45) labeled plastic buckets with drainage holes at the base. The soils contained in the buckets were polluted with $200 \mathrm{ml}$ of crude oil each except the pristine control and were mixed thoroughly and allowed for 14 days. Soil samples were collected for microbial analysis after three weeks of soil treatment. The result showed that the combined treatment (cow dung + plantain peels) yielded the highest crude oil-utilizing bacteria (CUB) counts of $11.73 \times 10^{4} \mathrm{CFUg}^{-1}$ at $750 \mathrm{~g}$. Also the combined treatment $(C D+P P)$ produced the highest crude-oil utilizing fungi (CUF) counts of $7.20 \times 10^{4} \mathrm{CFUg}^{-1}$ at 750 g. Twelve bacterial genus: Bacillus sp., Staphylococcus aureus, Actinomyces sp., Pseudomonas aeruginosa, Micrococcus sp., Achromobacter sp., Flavobacterium sp., Escherichia coli, Campylobacter sp., Serriatia marcescon, Enterobacter sp., Corynebacterium sp.; and eight fungal species: Fusarium sp., Chrysosporium sp., Aspergillus sp., Penicillum sp., Yeast sp., Rhizopus sp., Trichoderma sp. and Mucor indicus were isolated. The result of the total hydrocarbon content (THC) analysis showed that the higher the concentration of the agro-wastes, the more the reduction of the hydrocarbon content. It therefore suggests that the combined treatment of cow-dung and plantain peels (CD + PP) should be considered as one of the best options for bioremediation of crude oil polluted soil.
\end{abstract}

Keywords: Biostimulation, microbial degradation, crude oil, cow dung, plantain peel.

${ }^{*}$ Corresponding author. E-mail: agborreagan@yahoo.com.

\section{INTRODUCTION}

Bio-stimulation is the addition of substances, vitamins, oxygen and other compounds that stimulate microorganism activity so that they can degrade the hydrocarbon faster. Activities are usually added to the sub-surface through injection walls. Bio-stimulation can be enhanced by bio-augmentation. This process, overall, is refers to as bioremediation (Tyagi et al., 2011). Crude oil exploration and exploitation had led to economic boom in oil producing countries thus providing raw materials for many petrochemical industry and serves as a source of energy. The availability and abundance of this product have led to increasing demands of oil to meet the world's energy need. The conveyance of petroleum product to distant places, sometimes result to its spill in terrestrial environment. Oil spill also result to an in balance carbonnitrogen ratio at the soil site. The presence of high level of crude oil in soil causes nitrogen deficiency in an oil contaminated soil which retards the growth of bacterial and the utilization of carbon source (Agbor et al., 2012). Bioremediation processes which take advantage of microbial degradation of organic and inorganic substances can be defined as the use of microorganism to remove environmental pollutant from soils, water and sediment (Pala et al., 2006). Bioremediation present countless advantages in relation to other processes employed to remove pollution such as extraction with solvent, addition of chemical oxidizers, etc. (Morelli et al; 2005; Demnerova et al., 2005). 
It has been known over time that certain micro-organisms possesses specific abilities to degrade petroleum hydrocarbons and use them as a sole source of carbon and energy for growth. Remediation of the contaminated soil can be done in many ways which include both physicochemical and biological methods. Biological methods are more economical and efficient than chemical and physical ones. In comparison to other biological method, bioremediation through microorganism is more efficient, but more solubility and absorption of high molecular weight hydrocarbons limit their availability to micro-organism (Thapa et al., 2012).

There are several clean-up techniques currently in use to clean up environmental pollutants. Methods include incineration, catalytic destruction (Donlon and Banda, 2010; Kumar et al., 2011), use of soil degrading microorganism, inorganic fertilizers, chicken droppings, periwinkle shells, etc. (Leahy and Cowell, 1990; ljah and Antai, 2003; ljah and Ndana, 2003). However, it has been reported that most of the techniques caused more damage than the pollutants itself (Danjuma et al., 2012). In response to the need for a cost effective and environmentally friendly clean-up methods, environmental bio-technologists have develop techniques such as bioremediation to clean up polluted environment (Agbor et al., 2012). The aim of this work is to investigate the potential of cow dung (CD) and plantain peels (PP) as stimulants of microbial degradation of crude oil in polluted soils.

\section{MATERIALS AND METHODS}

The crude oil (Bonny light) was obtained from the Nigerian Agip Oil Company, Port-Harcourt, Rivers State, Nigeria. While the plantain peels was collected from roasted plantain sellers at MCC Road, Calabar, Cross River State and cow dung was collected from Ikot Eneobong abattoir, 8miles, Calabar. The collected wastes (cow dung and plantain peels) were sun dried and processed to powder. The powdered sample was sieved to pass through $2 \mathrm{~mm}$ sieve and were labeled and stored in containers. Top soil (0 to $20 \mathrm{~cm}$ depth) was collected from four points, using a Dutch auger, then bulked to form a composite sample. Eight kilograms $(8 \mathrm{~kg})$ each of the composite soil was weighed and transferred into forty-five (45) labeled plastic buckets with drainage holes at the base. The plastic buckets were arranged in triplicate in a completely randomized design. The soils were polluted with $200 \mathrm{ml}$ of crude oil each except the pristine control. The polluted soil contained in the plastic buckets were thoroughly mixed and allowed to stand for 14 days for acclimatization between the soil and the oil. Different treatment groups were applied to each plastic buckets, in single forms $\left(\mathrm{COC}_{1}\right.$, 250CD, 500CD, 750CD, $\left.\mathrm{COC}_{2}, 250 \mathrm{PP}, 500 \mathrm{PP}, 750 \mathrm{PP}\right)$ and in combined forms $\left(\mathrm{COC}_{3}, 250 \mathrm{CD}+250 \mathrm{PP}, 500 \mathrm{CD}+500 \mathrm{PP}\right.$ and 750CD + 750PP). After soil amendments, soil samples were taken for laboratory analysis. The total heterotrophic bacteria (THB) counts were determined using the spread plate method on nutrient agar (NA) according to APHA (1998), as adopted from Agbor et al. (2012). The procedure of Hamamura et al. (2006) as adopted by Agbor et al., (2012) was used in the determination of crude oil utilizing bacteria. The method of Sexton and Atlas (1977) was used in determining the total fungi count. The amount of crude oil in the soil sample was determined using air dried soil that was sieved through $1 \mathrm{~mm}$ mesh. One gram of the soil sample was suspended in $10 \mathrm{ml}$ of hexane and shaken for 10 min using a mechanical shaker. The solution was filtered using What-man filter paper into $50 \mathrm{ml}$ of hexane (Akpoveta et al., 2011). The absorbance of this solution was read at $430 \mathrm{~mm}$ with Jenway model $6405 \mathrm{Uv} / \mathrm{v}$ spectrophotometer using n-hexane as blank (Agbor, 2012). Data collected were subjected to a two-way analysis of variance (ANOVA) test and significant means were separated using least significance difference (LSD) at $5 \%$ probability level.

\section{RESULTS AND DISCUSSION}

The result obtained showed that the soil amended with $750 \mathrm{~g} \mathrm{CD}+750 \mathrm{~g}$ PP had significantly higher $(\mathrm{P}<0.05)$ THBC $(11.73 \pm 0.88 \mathrm{CFU} / \mathrm{g})$ than other amended soils. These were followed by the THBC in soil amended with $500 \mathrm{~g} \mathrm{CD}+500 \mathrm{~g}$ PP which had mean counts of $9.53 \pm$ $1.76 \times 10^{4} \mathrm{CFU} / \mathrm{g}$, also followed by the mean counts in soil amended with $750 \mathrm{~g}$ PP with counts of $8.23 \pm 1.20 \times$ $10^{4} \mathrm{CFU} / \mathrm{g}$. Other amended soils had no variations in the counts obtained in the pristine control and crude oilpolluted control soils. It was observed from the results that the soil amended with $750 \mathrm{~g} \mathrm{CD}+750 \mathrm{~g} \mathrm{PP}$ produces higher THFC than other amended soils. These were followed by soils amended with 500CD + 500PP and 750PP that showed no variation in the mean counts obtained. Then followed by the soil amended with 500PP, $750 \mathrm{CD}$ and $\mathrm{COC}$ which had mean counts of $2.33 \pm 4.06$ $\times 10^{4} \mathrm{CFU} / \mathrm{g}, 2.47 \pm 2.40 \times 10^{4} \mathrm{CFU} / \mathrm{g}$ and $2.20 \pm 1.16 \times$ $10^{4} \mathrm{CFU} / \mathrm{g}$ respectively, with no variation in the mean THFC obtained. Other amended soil had significantly reduced THFC in the soils. The increase in the microbial population of the soil resulted in the reduction of the total petroleum hydrocarbon content of the soil in soil amended with $750 \mathrm{~g} \mathrm{CD}+750 \mathrm{~g} \mathrm{PP}$ and $500 \mathrm{~g} \mathrm{CD}+500$ $\mathrm{g}$ PP which had mean counts of $184.67 \pm 0.88 \mathrm{mg} / \mathrm{kg}$ and $193.33 \pm 2.03 \mathrm{mg} / \mathrm{kg}$ respectively, with no significant difference $(P<0.05)$ in the mean values obtained. These were followed by the mean reduction in the TPH in soil amended with 250PP, 500PP and $250 \mathrm{~g} \mathrm{CD}+250 \mathrm{~g}$ PP which had mean of $231.0 \pm 1.53,218 \pm 1.15 \mathrm{mg} / \mathrm{kg}$ and $225.67 \pm 0.88 \mathrm{mg} / \mathrm{kg}$ respectively with no variation in the mean values obtained. The crude oil polluted control had the highest TPH content $(456.33 \pm 1.67 \mathrm{mg} / \mathrm{kg})$ in the soil (Table 1). Persistence of pollutants in the environment for a long period is partly due to low number of hydrocarbon utilizers and the toxicity of oil to speed up the biological breakdown of hydrocarbons in soil, bio-stimulation of the intrinsic micro-organisms by addition of nutrients is the most frequently used bioremediation technique (Margesin and Schinner, 2001). Cow dung, plantain peel and cow dung + plantain peels are agro-wastes with no known toxicity implication on microbial activity in soil but with bioremediation potentials of increasing the microbial population in crude oil contaminated soil. It was also observed from this study that the amendments increased the total heterotrophic and crude oil utilizing bacteria and fungi population of the amended soil. It was also 
Table 1. Microbial population of crude oil polluted soils amended with cow dung and plantain peels.

\begin{tabular}{|c|c|c|c|c|c|}
\hline Sample code & THBC $\times 10^{3}(\mathrm{CFU} / \mathrm{g})$ & THFC $\times 10^{3}(\mathrm{CFU} / \mathrm{g})$ & CUB $\times 10^{3}(\mathrm{CFU} / \mathrm{g})$ & CUF $\times 10^{3}(\mathrm{CFU} / \mathrm{g})$ & TPH (mg/kg) \\
\hline $\mathrm{PC}$ & $2.93 \pm 0.33^{d}$ & $1.33 \pm 0.88^{d}$ & $2.10 \pm 1.16^{\dagger}$ & $2.33 \pm 1.20^{\mathrm{e}}$ & $20.46 \pm 0.29^{a}$ \\
\hline $\mathrm{COC}$ & $3.4 \pm 1.16^{d}$ & $2.20 \pm 1.16^{\mathrm{c}}$ & $3.0 \pm 1.16^{\mathrm{e}}$ & $2.90 \pm 0.58^{\mathrm{e}}$ & $456.33 \pm 1.67^{\mathrm{a}}$ \\
\hline $250 \mathrm{CD}$ & $1.6 \pm 1.00^{\mathrm{d}}$ & $1.07 \pm 0.67^{d}$ & $4.13 \pm 1.76^{d}$ & $1.4 \pm 1.16^{f}$ & $297.33 \pm 1.67^{b}$ \\
\hline $500 \mathrm{CD}$ & $2.73 \pm 1.76^{d}$ & $1.4 \pm 1.16^{d}$ & $4.77 \pm 1.45^{\mathrm{c}}$ & $2.67 \pm 2.85^{\mathrm{e}}$ & $288 \pm 1.15^{\mathrm{c}}$ \\
\hline $750 C D$ & $4.03 \pm 0.88^{d}$ & $2.27 \pm 2.4^{c}$ & $5.67 \pm 2.40^{\mathrm{a}}$ & $3.77 \pm 1.45^{\mathrm{C}}$ & $247.33 \pm 3.85^{d}$ \\
\hline 250PP & $2.17 \pm 1.45^{\mathrm{d}}$ & $1.20 \pm 1.16^{d}$ & $1.63 \pm 1.76^{\dagger}$ & $2.17 \pm 0.88^{\mathrm{e}}$ & $231.0 \pm 1.53^{\mathrm{e}}$ \\
\hline 500PP & $4.87 \pm 3.48^{d}$ & $2.33 \pm 4.06^{\mathrm{c}}$ & $2.07 \pm 0.88^{f}$ & $2.57 \pm 0.88^{\mathrm{e}}$ & $218 \pm 1.15^{\mathrm{e}}$ \\
\hline 750PP & $8.23 \pm 1.20^{c}$ & $3.53 \pm 1.76^{b}$ & $3.20 \pm 1.16^{\mathrm{e}}$ & $3.80 \pm 1.16^{c}$ & $199.67 \pm 0.88^{f}$ \\
\hline $250 C D+250 P P$ & $2.13 \pm 2.73^{d}$ & $1.33 \pm 1.76^{d}$ & $3.47 \pm 2.4^{\mathrm{e}}$ & $3.33 \pm 0.67^{d}$ & $225.67 \pm 0.88^{e}$ \\
\hline $500 C D+500 P P$ & $9.53 \pm 1.76^{b}$ & $3.53 \pm 1.76^{\mathrm{b}}$ & $4.90 \pm 1.53^{b}$ & $4.56 \pm 1.20^{b}$ & $193.33 \pm 2.03^{f}$ \\
\hline $750 C D+750 P P$ & $11.73 \pm 0.88^{\mathrm{a}}$ & $4.33 \pm 1.76^{\mathrm{a}}$ & $5.97 \pm 0.88^{\mathrm{a}}$ & $7.20 \pm 1.16^{a}$ & $184.67 \pm 0.88^{\dagger}$ \\
\hline LSD & 8.86 & & & & \\
\hline
\end{tabular}

Key: THBC - Total heterotrophic bacteria count; THFC - Total heterotrophic fungi count; CUB - Crude oil utilizing bacteria; CUF - Crude oil utilizing fungi; TPH - Total petroleum hydrocarbon.

observed that high concentration of the amendments increases the microbial counts of the soil than lower concentration of the amendment. The addition of agrowaste (cow-dung, plantain peels and combination of cow dung + plantain peels) shows that the significant difference $(P<0.05)$ exists among the amendments in microbial population. However, among the single amendments used the result shows that plantain peels significantly increased $(P>0.05)$ of the mean count obtained in the soil than cow dung but the combination of cow dung and plantain peels shows a higher microbial counts than the single amendments. The total heterotrophic and crude oil utilizing bacteria and fungi from CD + PP is higher than that of CD and PP, thus this is an indication that the combination of these amendments has stronger bio-utilization potentials because of the presence of acclimated microorganisms found in the single amendments, that can significantly affect the degradation rate of the contaminants. Sexton and Atlas (1997) reported that a combination of amendments in the right proportions would be effective in degradation of crude oil in polluted soil. The soil amended with the various concentrations of cow dung, plantain peels and cow dung + plantain peels showed that they were significantly increased $(P<0.05)$ in the microbial counts of heterotrophic and crude oil utilizing fungi. Table 2 showed that twelve (12) bacterial species were identified in the agro-waste amended soil samples.
They include Bacillus sp., Staphylococcus aureus, Actinomyces sp., Pseudomonas aeruginosa, Micrococcus sp., Achromobacter sp., Flavobacterium sp., Escherichia coli, Campylobacter sp., Serriata marcesceri, Enterobacter sp., Corynebacterium sp. This is in agreement with the findings of Lakova (2000) and Mansour et al. (1999) who reported that many microorganisms have been seen present in pig dung, which include bacteria and fungi. Though Bacillus $s p$ and Achromobacter sp. were the most predominant bacterial species, their prevalence could be attributed to the fact that they form spores, which help microorganisms to withstand harsh conditions, such as sun drying during this work. Mansour et al. (1999) reported on the isolation of Bacillus, Acinetobacter, Staphylococcus and Enterobacter among other bacteria from pig dung. Eight (8) fungi species were also identified they include the following: Fusarium sp., Trichoderma sp., Chrysoporium sp., Aspergillus sp., Penicillum sp., Yeast sp., Rhizopus sp. and Mucor indicus (Table 2). The duration was also observed as an important factor in the proliferation of bacteria population in the soil. The crude oil polluted control had the highest TPH content in the soil. This correlates the findings of an earlier worker (Abioye and ljah, 2009) who observed higher percentage of crude oil loss in the $5 \%$ used motor oil polluted soil sample amended with organic waste when compared with that of $15 \%$.

Table 2. Cultural characterization and identification of fungi isolate.

\begin{tabular}{lllll}
\hline Sample code & Isolates & $\begin{array}{l}\text { Cultural or macroscopic appearance of } \\
\text { fungi isolates }\end{array}$ & $\begin{array}{l}\text { Microscopic appearance } \\
\text { isolates }\end{array}$ & $\begin{array}{l}\text { fungi Probable } \\
\text { organism }\end{array}$ \\
\hline PC & IS1 & $\begin{array}{l}\text { Rapid growing colony, that was worthy } \\
\text { initially and as it grows old becomes } \\
\text { compact with green patches }\end{array}$ & $\begin{array}{l}\text { Flask-shape phialides and vertically } \\
\text { arranged conidiosphore }\end{array}$ \\
\hline
\end{tabular}


Table 2. Continues.

\begin{tabular}{|c|c|c|c|c|}
\hline & IS2 & $\begin{array}{l}\text { Rapid growing colony, worthy initially at } \\
\text { 48hours cultured and later turns cotton-like } \\
\text { on appearance flat on the agar surface and } \\
\text { fast spreading }\end{array}$ & $\begin{array}{l}\text { The conidiosphore occurred in } \\
\text { sickled shape and the conidia was } \\
\text { multicelled and singled }\end{array}$ & Fusarium spp. \\
\hline & IS3 & $\begin{array}{l}\text { Moderate fast growing colony, initially white } \\
\text { at } 48 \text { hours cultured and becomes tan in } \\
\text { colour as its grows old. }\end{array}$ & $\begin{array}{l}\text { Vegetative hyphae and the conidia } \\
\text { was puriform }\end{array}$ & $\begin{array}{l}\text { Chrysosporium } \\
\text { spp. }\end{array}$ \\
\hline \multirow{2}{*}{$\mathrm{COC}$} & IS1 & $\begin{array}{l}\text { Rapid growing colony and brownish velvety } \\
\text { in appearance }\end{array}$ & $\begin{array}{l}\text { Narrow spherical head that is } \\
\text { covered with phalides and septaate } \\
\text { hyphae }\end{array}$ & Aspergillus spp \\
\hline & IS1 & $\begin{array}{l}\text { Greenish, velvety and wrinkled in } \\
\text { appearance colony }\end{array}$ & $\begin{array}{l}\text { The conidiosphore produce head that } \\
\text { are composed of branches. The } \\
\text { phialides arranged in brush-like } \\
\text { pattern. }\end{array}$ & Penicillium spp. \\
\hline \multirow{3}{*}{$\begin{array}{l}250 \mathrm{gCD} \\
750 \mathrm{gCD}\end{array}$} & IS2 & $\begin{array}{l}\text { Moderate fast growing colony, initially white } \\
\text { and becomes tan in colour }\end{array}$ & $\begin{array}{l}\text { Vegetative hyphae and the conidia } \\
\text { was typically puriform }\end{array}$ & Chrysoporium \\
\hline & IS3 & $\begin{array}{l}\text { White to cream colony, soft, smooth and } \\
\text { bacteria-like in appearance }\end{array}$ & $\begin{array}{l}\text { Oval and elongated budding yeast } \\
\text { cells }\end{array}$ & Yeast spp. \\
\hline & IS1 & $\begin{array}{l}\text { Colony was shades of green, wrinkled and } \\
\text { velvety in appearance }\end{array}$ & $\begin{array}{l}\text { The conidiosphore produced head } \\
\text { that are composed of short branches. } \\
\text { The phialides are arranged in brush- } \\
\text { like pattern. }\end{array}$ & Penicillium spp. \\
\hline \multirow[t]{3}{*}{$\begin{array}{l}250 \mathrm{gPP} \\
750 \mathrm{gPP}\end{array}$} & IS2 & $\begin{array}{l}\text { Fast growing colony, shades of white to dark } \\
\text { gray }\end{array}$ & Non-septate hyphae, long and erect & Rhizopus spp. \\
\hline & IS1 & $\begin{array}{l}\text { Rapid growing colony and brownish velvely } \\
\text { in appearance }\end{array}$ & $\begin{array}{l}\text { Narrow spherical head that is } \\
\text { covered with phialides and septate } \\
\text { hyphae }\end{array}$ & Aspergillus spp \\
\hline & IS2 & $\begin{array}{l}\text { Fast growing colony, fluffy while in } \\
\text { appearance }\end{array}$ & $\begin{array}{l}\text { Large spherical head produced by } \\
\text { the conidiosphore aseptate broad } \\
\text { hyphae. }\end{array}$ & Mucor indicus \\
\hline \multirow[t]{2}{*}{$\begin{array}{l}250 \mathrm{gCD}+\mathrm{PP} \\
-750 \mathrm{gCD}+ \\
\mathrm{PP}\end{array}$} & IS3 & $\begin{array}{l}\text { Colony was shades of green, wrinkled and } \\
\text { velvely in appearance }\end{array}$ & $\begin{array}{l}\text { The conidiosphore produced head } \\
\text { that are composed of short branches. } \\
\text { Brush-like pattern arranged } \\
\text { phialides. }\end{array}$ & Penicillium spp. \\
\hline & IS4 & $\begin{array}{l}\text { Fast spreading, rapid growing colony was } \\
\text { initially wolly and later becomes cotton-like } \\
\text { in appearance }\end{array}$ & $\begin{array}{l}\text { The conidiosphore occurred in } \\
\text { sickled shape and the conidia was } \\
\text { multicelled. }\end{array}$ & Fasarium spp. \\
\hline
\end{tabular}

\section{CONCLUSION}

Since the population of the crude oil-utilizing microorganism (bacteria and fungi) increased compared to the controls and the total hydrocarbon content of the treated soils decreased simultaneously, it means that the agrowastes applied as amendment were effective in stimulating the growth of indigenous crude oil-utilizing microorganism.

\section{REFERENCES}

Abioye OA, ljah UJJ, 2009. Biodegradation of crude oil in soil amended with melon shell. Aust J Technol, 13(10): 34-38.

Agbor RB, Ekpo IA, Osuagwu AN, Udofia UU, Okpako EC, Antai SP, 2012. Biostimulation of microbial degradation of crude oil polluted soil using cocoa pod husk and plantain peels. J Microbiol Biotechnol Res, 2(3): 464-469.

Akpoveta OV, Egharevba F, Medjor OW, Osaro KI, Enyemike ED, 2011. Nierob oil degradation and its kinetics on crude oil polluted soil. Res J Chem Sci, 1(16): 8-14. 
APHA, 1998. Standard Methods for the Examination of water waste $20^{\text {th }}$ ed. American Public Health Association. EAPHA - ANWA - WPCF. Washington; DC.

Danjuma BY, Adusalam S, Sulaiman ADI, 2012. Kinetic investigation of escravas crude oil contaminated soil using natural stimulants of plant sources. Int J Emerg Trend Eng Dev, 2(2): 4478-4486.

Demnerova K, Maclova M, Spevakova V, Beranova K, Kochankova L, Loveck P, Ryslava E, Macek T, 2005. Two approaches to biological decontamination of ground water and soil polluted by aromatics characterization of microbial population. Int Microbiol, 8(2): 205-211.

Donlon DL, Bander JW, 2010. A general essay on bioremediation of crude oil. Retrieved from http//www.waterquality.montana.edu/docs/ methane/donlon.shtml on $29^{\text {th }}$ May, 2014.

Hamamura N, Olson SH, Ward DM, Inskeep WP, 2006. Microbial population dynamics associated with crude oil degradation in diverse soil. Appl Environ Microbiol, 72: 6316-6324.

Ijah UJJ, Antai SP, 2003. The potential use of chicken-drop microorganisms for oil spill remediation of crude oil in soil amended with periwinkle shells. The Environmentalist, 23: 89-95.

Ijah UJJ, Ndana M, 2003. Stimulated biodegradation of crude oil in soil amended with periwinkle shells. The Environmentalist, 23: 249-54.

Kumar A, Bishiet BS, Joshi VD, Dhewa T, 2011. Review on bioremendiation of polluted environment: A management tool. Int $\mathrm{J}$ Environ Sci, 6(1): 1079-1092.

Leahy JC, Colwell RR, 1990. Microbial degradation of hydrocarbons in the environment. J Microbiol Rev, 54: 305-515.

Margesin R, Schinner F, 2001. Bioremediation (natural attenuation and biostimulation) of diesel oil contaminated soil in al Alpine glacier skiling Area. Appl Environ Microbial, 67(1): 3127-3133

Morelli IS, Del Panno MT, De Antoni GL, Painceira MT, 2005. Laboratory study on the bioremediation of petrochemical sludge contaminated soil. Int Biodeteriorat Biodegradat, 55(4): 271-278.

Pala MD, De Carvalho D, Pinto PC, Sant Anna Jr. GL, 2006. A suitable model to describe bioremediation of a petroleum contaminated soil. Int Biodeteriorat Biodegrad, 58(6): 254-260.

Sexton AJ, Atlas RM, 1997. Response of microbial populations in arctic tundra soil crude oil. Canadian J Microbiol, 23: 1327-1333.

Thapa B, Kumar A, Ghimire A, 2012. A review of on bioremediation of petroleum hydrocarbon contaminants in soil. J Sci Eng Technol, 8(1): 164-170.

Tyagi L, Garg PO, Gosavi KJ, 2011. Bioremediation: An overview. Pure Appl Chem, 73(7): 1163-1172.
Citation: Agbor RB, Antai SP, 2018. Bio-stimulation of microbial degradation of crude oil polluted soil using cow dung and plantain peels. Int J Ecol Ecosolution, 5(1): 8-12. 